\title{
Chinese Financial Regulation with International Capital Flows - Based on Capital Flows between China and the US study
}

\author{
Qiqi Han ${ }^{1, a}$, Xiangyu Yang ${ }^{2, b,{ }^{*}}$ \\ ${ }^{1}$ Beijing Jiaotong University,Beijing,China \\ 2 Beijing Jiaotong University,Beijing,China \\ a15120545@bjtu.edu.cn, bxyyang@bjtu.edu.cn \\ ${ }^{*}$ Qiqi Han
}

\section{Keywords: Financial regulation, Capital Flows, interest rate}

\begin{abstract}
China's economic and social development is moving toward a new era, the development of China's financial industry is also facing new opportunities in recent years, China's financial market is trying to break the traditional model, the strict financial controls are being gradually liberalized, market-based interest rates and exchange rates and RMB internationalization process is well underway forward. This paper uses gray correlation study of the correlation between financial regulation and capital flows, the relationship and its degree of influence is analyzed from three aspects: national saving rate, import and export, and foreign investment rate. Finally, the conclusion is drawn that there is correlation between financial regulation and capital flow. And then put forward relevant policy recommendations.
\end{abstract}

\section{Introduction}

Financial regulation is the management and restriction of a government in all aspects of financial institutions and financial market activities in order to maintain the stable operation of the financial system and overall efficiency. In 1863 the United States Congress passed the "National Monetary Law", was the world's first legal form to determine the financial regulatory system. Germany and Japan have also experienced a development from a decentralized, more liberal banking system to a monetary banking system. In short, the monopoly of the currency issue is the first step in the initial control of the financial industry, the specific sign is the central bank have established. The Great Depression of the United States from 1929 to 1933 was a watershed in the US financial industry from free development to full control, and the crisis completely shook the confidence of the market. Since then, with the financial internationalization and the development of global economic integration, the financial markets of various countries are also facing more and more risks, the financial crisis broke out from time to time. With the diversification of the forms of financial crisis, the scope of influence is more and more extensive and deeper, and countries have taken different actions of financial control in different periods.

The development of China's economic and social is moving to a new era, and the development of China's financial industry is also facing new opportunities. In recent years, China's financial market is breaking the traditional model, the strict financial controls are being gradually liberalized, market-based interest rates and exchange rates, as well as the process of internationalization of the $\mathrm{RMB}$ is moving forward methodically. China's economy is taking off and is becoming an international market for many investors to pay close attention to. However, China's financial market has not yet reached a mature level. With the continuous inflow of capital, it has brought about the growth of the national economy. On the other hand, it also brought impact to China's unstable financial market. Exploring the relationship between financial control and capital flows, can help us understand the differences and the relationship between China and other financial markets, so as to find China's own financial control model. 


\section{Theoretical Analysis of Financial Regulation and Capital Flow}

2.1 Financial Control. Financial regulation can be defined as a government arrangement to ensure the financial system's stability, security and the investors' interests, which is resulting from the partial and overall outburst of the financial market crisis.

China is different from the Western countries, resorted a comprehensive financial control model at the beginning, started research financial control relatively late and targeted, focused on system design and specific measures. Li Hong (2006) studied the financial regulation on the basis of the general industrial control model, drew a conclusion that financial regulation is bound to the institutional background to some extent, which resulted from establishing a financial control model. Cui Peng (2007) demonstrated the importance of financial regulation in China's current situation and suggested that China should learn from foreign financial control experience through innovation to establish a situation in line with China's national conditions and that financial control system should take with Chinese characteristics.

2.2 Theoretical Analysis of Capital Flow.International capital flows, in short, refer to the transfer of capital in the international arena.Wang Qi (2006) put forward a model of influencing factors of China's international capital flows based on the theory of influencing factors of international capital flows, and used the multiple regression analysis, it was proved that the factors influencing the capital flow in China are economic variables such as exchange rate, interest rate, inflation rate, openness and policy. With the development trend of the gradual integration of the global economy, the factors influencing the capital flow are becoming more and more diversified and complicated.

2.3 The Association between Financial Regulation and Capital Flows. According to the above factors that affect the capital flow can be determined, financial control and capital flows have a certain relevance. Financial regulation affects international flows of capital by acting on instruments such as interest rates, exchange rates, and currencies.

First, the most obvious factor is the interest rate factor. This paper is based on the capital flow between China and the United States. China's interest rate market reform has been carried out for 20 years. The current interest rate market promotion has come to the final stage, that is, the liberalization of the deposit interest rate market. The gradual marketization of interest rates also means the gradual liberalization of financial regulation, which also has an indispensable impact on capital flows.

Second, the exchange rate is also a major object of China's reform. China's exchange rate system has also undergone many changes. With the gradual easing of capital account control in China over the past two years, the scale of capital flows has been widened and the volatility of domestic liquidity has also increased. From the outside, the United States began to raise interest rates, increased attractiveness to international capital, indicating the current pressure of capital outflows.

Finally, FDI is the most direct expression of capital flows. China is the most restrictive economy in the BRIC countries, especially in the media, finance and transportation. In 2014, China's FDI inflows grew moderately by $3 \%$, making it the world's largest recipient of FDI for the first time in history. China's FDI growth in 2010 was $6.4 \%$, the scale reach a new level

\section{Empirical Analysis}

3.1 Index Selection. Financial controls act on interest rates, exchange rates and FDI, thereby affecting national savings rates, imports and exports, and national investment rates. Therefore, the national savings rate (national savings/GDP), openness (net exports/GDP), the United States on China OFDI (China to absorb US FDI/GDP) as an independent variable. Select net capital inflow, divided by GDP to get capital liquidity as the dependent variable. Then analyze China's savings and investment behavior since 2006 based on the data provided by the China Statistical Yearbook 2006-2014. According to the import and export trade volume, divided by GDP a year to get the degree of openness arguments, trying to measure the extent of capital flows through savings rates and absorption of foreign investment rates and openness.

3.2 Gray Correlative Degree Analysis. In this paper, the gray relational analysis method is used to analyze the relationship between national savings rate, openness and the relationship between China's 
investment rate and capital flow and determine whether it is relevant. Based on the above variables, select the relevant data from 2006 to 2014, the related data is shown in Table 4-1.

Table 4-1. Capital Flows and Their Influencing Factors

\begin{tabular}{|c|c|c|c|c|}
\hline Year & Capital flow & Openness & Savings Rate & American to China's OFDI \\
\hline 2006 & 20.28 & 120.90383 & 0.743796681 & 1.318819259 \\
\hline 2007 & 20.39 & 112.4468732 & 0.642272076 & 0.973912169 \\
\hline 2008 & 18.74 & 104.7082059 & 0.683590405 & 0.923753054 \\
\hline 2009 & -3.33 & 86.44130181 & 0.75575824 & 0.740477223 \\
\hline 2010 & 67.32 & 94.65721188 & 0.744962737 & 0.741110258 \\
\hline 2011 & 90.8 & 93.1202097 & 0.716540899 & 0.494044637 \\
\hline 2012 & -3.67 & 90.95508097 & 0.749806567 & 0.487563526 \\
\hline 2013 & 102.85 & 89.29212048 & 0.767496747 & 0.48351954 \\
\hline 2014 & 25.02 & 87.18389131 & 0.762118062 & 0.372332138 \\
\hline
\end{tabular}

Note: China Statistical Yearbook (2006-2014)

First of all, because the meaning of the various factors in the system, resulting in the data is not necessarily the same dimension, it's not easy to compare and get the correct conclusion. Therefore, in the gray correlation analysis, the general must be non-dimensional data processing. In this paper, the initial value method is used to dimension the data to eliminate the influence of different orders of magnitude. The data obtained after dimensionless is shown in Table 4-2.

Table 4-2.Normalized Capital Flows and Their Influencing Factors

\begin{tabular}{|c|c|c|c|c|}
\hline Year & Capital flow & Openness & Savings Rate & American to China's OFDI \\
\hline 2006 & 1 & 1 & 1 & 1 \\
\hline 2007 & 1.005424063 & 0.930052201 & 0.863504896 & 0.738472814 \\
\hline 2008 & 0.924063116 & 0.8660454 & 0.919055467 & 0.700439463 \\
\hline 2009 & -0.164201183 & 0.714959169 & 1.016081759 & 0.561469828 \\
\hline 2010 & 3.319526627 & 0.782913261 & 1.001567709 & 0.56194983 \\
\hline 2011 & 4.477317554 & 0.77020066 & 0.963355871 & 0.37461133 \\
\hline 2012 & -0.180966469 & 0.752292801 & 1.008080012 & 0.369697002 \\
\hline 2013 & 5.071499014 & 0.738538394 & 1.031863635 & 0.366630633 \\
\hline 2014 & 1.233727811 & 0.721101154 & 1.024632244 & 0.282322339 \\
\hline
\end{tabular}

After the standardized data is obtained, the data is subjected to poor sequence and absolute value, according to the formula, where $\zeta$ is the resolution coefficient, $0<\zeta<1$. Take the resolution coefficient $\zeta$ as 0.5 , get the gray relational table of capital flows and three related factors, as shown in Table 4-3.

Table 4-3 Gray Relational Grade of Capital Flow and Its Influencing Factors

\begin{tabular}{|c|c|c|c|}
\hline Year & Openness & Savings Rate & American to China's OFDI \\
\hline 2006 & 1 & 1 & 1 \\
\hline 2007 & 0.968954743 & 0.943103824 & 0.898086305 \\
\hline 2008 & 0.975930772 & 0.997875812 & 0.913191525 \\
\hline 2009 & 0.727948435 & 0.665899392 & 0.764247495 \\
\hline 2010 & 0.481164105 & 0.503690832 & 0.460357951 \\
\hline 2011 & 0.388219219 & 0.40100161 & 0.364428043 \\
\hline 2012 & 0.71596277 & 0.664251597 & 0.810318654 \\
\hline 2013 & 0.351876629 & 0.368023872 & 0.333333333 \\
\hline 2014 & 0.82107652 & 0.918370823 & 0.712030374 \\
\hline Gray Correlation Degree & 0.714570355 & 0.718024196 & 0.695110409 \\
\hline
\end{tabular}

From the gray correlation degree of the last row of the above table, we can see that the correlation between capital flow and openness is 0.714570355 , the correlation with the savings rate is 
0.718024196, and the correlation with the US OFDI is 0.695110409 under the condition that the resolution coefficient $\zeta$ is 0.5 . If the gray correlation is greater than 0.65 , then the two are related, it is clear that capital flows and China's openness, the national savings rate and the United States on China OFDI are related, and the degree are similar. First, the higher the degree of openness, the more trade, the trade with capital flows, so the two have a high correlation. Second, when a country's deposit interest rates are higher, will attract more savings, the higher the national savings rate, the capital outflow will be relatively less. Finally, now that China gradually abolished restrictions on foreign FDI, China's absorption of US direct investment get more and more, means that capital inflows, increases capital mobility.

To sum up, we can get a conclusion that China's financial control is related to capital flow.

\section{Policy Recommendations}

4.1 Strengthen Capital Inflow Management. Global action on international capital flow management should be initiated.China can respond to international capital flows through stable exchange rates, stable and effective investment, issuance of government bonds and strengthening Sino-US cooperation. In order to better cope with capital flight, China should stabilize the RMB exchange rate policy, adopt temporary capital control measures, continue to promote exchange rate reform, build cross-border capital flow management and external debt macro-prudential policy framework, and orderly promote capital projects can be changed.

4.2 Strengthen the Continuous Innovation of Financial Control Mechanism. First, the government should study the international financial institutions of the business level, and constantly expand the regulatory level, innovation and financial regulatory mechanisms. Secondly, they should rely on a multi-level financial supervision system, in order to three-dimensional, flexible point of view of supervision, in order to achieve appropriate and reasonable degree of financial control, and further form an efficient financial system and regulatory system.

4.3 Establish A Financial Control System with Chinese Characteristics. China is different from the Western countries, economic and financial markets have not yet fully liberalized, so they can't fully learn from the measures of Western financial control, they should be based on their own situation, at the same time choose to learn from foreign successful experience, and develop China's own financial control program. China 's central bank should strive to create a satisfactory regulatory framework, it can not only promote better development of financial markets, but also protect the Chinese economy from the risk of capital flows

\section{References}

[1] Peng Cui, Analysis and Thinking on China 's Financial Regulation, Economic aspect, pp. 86-86,2007.

[2] Yukun Cui and Jianqing Zhi, Comparative Analysis of the Evolution of Financial Regulation in China and America, North China Finance, pp.15-18,2016.

[3] Hong Li, Economic Analysis of Financial Regulation, Finance and Economics Research, pp.65-72,2006.

[4] Liya Liu, Tianxiao Cheng, Yizhong Guan and Xiaolei Liu,Effects of Capital Regulation on Capital Flow Fluctuation, International Finance Research, pp.37-46,2013. 